\title{
Folic acid and mental symptoms in children with epilepsy
}

\author{
MICHAEL R TRIMBLE, * JOHN A CORBETT, $\dagger$ AND DAVID DONALDSON \\ From the National Hospital, London,* The Bethlem Royal Hospital, London $\dagger$ and Redhill General Hospital, \\ Surrey $\ddagger$
}

SUMMARY 312 children resident at a hospital school received a neuropsychiatric examination and information was provided on their IQ status. Children with a fall in their IQ were identified. Serum and red cell folate values were estimated and the relationship between neuropsychiatric disturbances and folate disturbances explored. Patients with a fall in IQ, neurotic disturbance and depression all had significantly lower serum folic acid levels than the rest of the population, and the children with neurotic disturbances and depression had significantly lower red cell folate values. The relationship between folic acid metabolism and the neuropsychiatric disturbances is discussed in the light of these findings.

For some years there has been a growing interest in the association between folic acid abnormalities and neuropsychiatric symptoms. Particular attention has been focused on observations that subnormal levels of serum folic acid are frequently found in epileptic patients, particularly those taking phenytoin. ${ }^{1}$ Patients with anticonvulsant-induced folate deficiency associated with neuropsychiatric illness such as dementia, or a schizophrenia-like psychosis have been described, who have responded to folic acid therapy. ${ }^{23}$ Further observations have shown that epileptic patients with abnormal mental states are more likely to have folate deficiency than those without, ${ }^{4}$ and the lowest levels are seen in patients with psychosis and dementia. ${ }^{1}$ All the studies on epileptic patients to-date have been on adults, and apart from giving an overall psychiatric diagnosis little attempt has been made to quantify the behaviour observed. In addition the majority of papers have only reported on serum folic acid levels, although Reynolds et $a l^{5}$ studied both serum and red cell folate levels in epileptic patients with psychiatric distubances and found that the red cell values were also disturbed. In order to explore this problem further a study was undertaken on a population of children with epilepsy resident at a hospital school. Serum and

Address for reprint requests: Dr MR Trimble, The National Hospital for Nervous Diseases, Queen Square, London WC1N 3BG.

Accepted 6 August 1980. red cell folate was estimated, as were the serum anticonvulsant levels. Attempts were made to evaluate the relationship between folic acid abnormalities and neuropsychiatric abnormalities.

\section{Materials and methods}

The investigation was carried out on 312 of 314 epileptic children resident at Lingfield Hospital School. The majority were on anticonvulsant therapy with two or more drugs. They received a neuropsychiatric examination and the presence of psychomotor slowing, depression and distractability was noted. These were scored on a four-point rating scale. In the analysis of the results a score of 0 to 1 was regarded as indicating that the abnormality was absent, and a score of 2 or 3 (that is moderate or severe) that it was present. Prior to the main study, a pilot study was carried out on 40 children to test the inter-observer reliability of these clinical ratings.

Additional information on the neuropsychiatric status of the children was obtained by two methods. First, the resident psychologist provided information on the IQ of the children. Of the 312 children, 204 had received more than one estimate of their IQ, and a small group whose IQ had actually deteriorated while they had been resident at the school were detected. The criterion for "fall in IQ" was a fall of greater than 10 points on two estimates of IQ (WISC or equivalent) done at an interval of more than one year. In addition, behaviour was rated using the Rutter A and B scales. ${ }^{6}$ These scales, the reliability and validity of which have been tested elsewhere, ${ }^{3}$ were scored in the standard way and provided estimates of behaviour deviance. Taking established cut- 
off points it was possible to select a group of children rated as deviant, and, by analysing the individual items, the deviance was scored as either neurotic disorder or conduct disorder. ${ }^{6}$ Neurotic disorder refers to behaviour where abnormality was manifest by symptoms of anxiety, depression, obsessions, compulsions or phobias. On the questionnaire children in this category would tend to provoke a reply of "yes" to such questions as "worries about many things" or "tends to be fearful or afraid of new things or situations". Conduct disorder is used to describe situations where anti-social symptoms, such as stealing, truanting, destructiveness and lying are prominent.

An early morning blood sample was taken in the fasting state on a date as near as possible to the neuropsychiatric examination. Serum folic acid was assessed by radio-immunoassay (Bio-Rad Laboratories, Quanta-count Folate Radioimmunoassay). For red cell folate values, a 1 in 20 dilution of whole blood was made in a $1 \%$ solution of ascorbic acid and the whole blood folate estimated. The results were then determined by applying a correction factor based on the haematocrit as measured on the Coulter Counter Model S.

\section{Results}

The inter-observer reliability between two examiners for the clinical neuropsychiatric estimates were: distractability $97.5 \%$, psychomotor slowing $79.5 \%$, and depression $87.2 \%$. This percentage agreement was satisfactory for the criteria to be included in the main study. Of the 312 children examined 219 were males and 287 were over the age of 10 years. Forty per cent of the children had an IQ greater than 70 , the mean full-scale IQ of the total sample was $66.2( \pm 18.8)$. The mean verbal and performance subscales, available on 244 children were $71.7( \pm 15.6)$ and 73.6 $( \pm 20 \cdot 4)$ respectively. The percentage of children with the neuropsychiatric abnormalities were $9.9 \%$ with distractability, $19.2 \%$ with psychomotor slowing and $5.1 \%$ with depression. Of the 204 children who had more than one estimate of their IQ, $31(15 \cdot 2 \%)$ were found to have an IQ fall of greater than 10 points. In the majority of children the fall was greater than 15 points, (range 10 to 48 ); $26.3 \%$ of the sample were scored as having neurotic disturbance, and $42 \cdot 3 \%$ as having conduct disturbance.

The mean serum folic acid levels for the whole population was $3.73 \mu \mathrm{g} / 1$ and the mean red cell folate was $48.45 \mu \mathrm{g} / 1$. Serum values of less than $3 \mu \mathrm{g} / 1$ were recorded in $48 \%$ of the sample, and a red cell folate of less than $50 \mu \mathrm{g} / 1$ was recorded in $69.0 \%$ of the total. Only $4.2 \%$ of the children had red cell levels greater than $100 \mu \mathrm{g} / 1$. The Pearson correlation coefficient between the red cell folate and serum folate was $r=0.54(n=293)$ $\mathrm{p}<0.001$. The mean red cell and serum folic acid values for the patients with neuropsychiatric abnormalities compared to the group without neuropsychiatric abnormalities are shown in table 1. This indicates that children with neurotic disorder, depression and fall in IQ have significantly lower mean serum folic acid levels than children without these disorders. In addition those with neurotic disorder and depression have significantly lower red cell folic acid levels than the rest of the children.

The normal red cell folate value for patients without epilepsy or known disorders of folate metabolism was $99 \cdot 19 \mu \mathrm{g} / 1 \pm 49.58$. All the results given in table 1 are significantly lower than these values $(p<0.001)$. These controls were from 96 patients aged 15-65 years, who had attended a general medical clinic.

There was no relationship between serum levels of phenytoin, phenobarbitone, or primidone, and the red cell folate levels, but children being prescribed phenytoin were over-represented in the group with serum folate values $<2 \mathrm{ng} / \mathrm{ml}$. ( $X=$ $15 \cdot 12$ DF $\mathrm{p}<0.001)$

\section{Discussion}

Several studies of both epileptic and non-epileptic patients with psychiatric disturbances have indicated a relationship of the latter to abnormalities of folate. These studies, summarised in table 2,

Table 1 Mean serum and red cell folic acid levels $(\mu \mathrm{g} / \mathrm{l} \pm$ standard deviations) in children with neuropsychiatric abnormalities

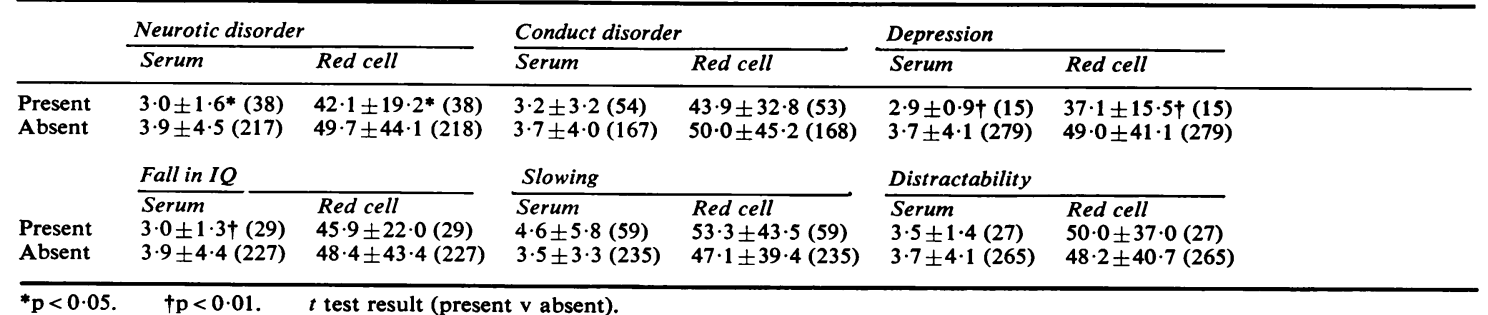


Table 2 Summary of studies on the relationship of folic acid to psychiatric illness

\begin{tabular}{|c|c|c|c|c|c|c|}
\hline Author & & Population & No & Serum folate & $R B C$ folate & Whole blood folate \\
\hline 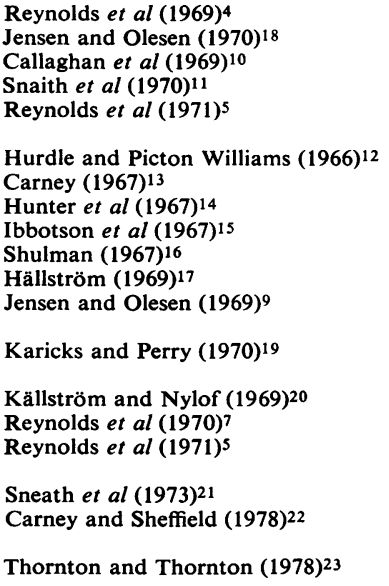 & $\begin{array}{l}\text { Various } \\
\text { "Deteriorated" } \\
\text { Psychosis } \\
\text { Various } \\
\text { Psychoses, behavioural, } \\
\text { affective disorders } \\
\text { Elderly without motivation } \\
\text { Various } \\
\text { Mental patients } \\
\text { Mental hospital patients } \\
\text { Elderly psychiatric patients } \\
\text { Mental patients } \\
\text { Psychoses, neuroses, } \\
\text { dementia } \\
\text { Psychiatric inpatients (many } \\
\text { epileptic) } \\
\text { Psychiatric patients } \\
\text { Depression } \\
\text { Psychoses, behaviour and } \\
\text { chronic affective disorder } \\
\text { Dementia } \\
\text { Psychiatric hospital } \\
\text { admissions } \\
\text { Psychiatric inpatients }\end{array}$ & $\begin{array}{l}\text { Epileptic adult } \\
\text { Epileptic adult } \\
\text { Epileptic adult } \\
\text { Epileptic adult } \\
\text { Epileptic adult } \\
\text { Adult } \\
\text { Adult } \\
\text { Adult } \\
\text { Adult } \\
\text { Adult } \\
\text { Adult } \\
\text { Adult }\end{array}$ & $\begin{array}{r}411 \\
115 \\
101 \\
\\
30 \\
14 \\
\\
272 \\
269\end{array}$ & $\begin{array}{l}\text { Reduced } \\
\text { Reduced } \\
\text { Reduced } \\
\text { Reduced } \\
\text { Reduced } \\
\text { Reduced } \\
\text { Reduced } \\
\text { Reduced } \\
\text { Reduced } \\
\text { Reduced } \\
\text { Reduced } \\
\text { Reduced }\end{array}$ & $\begin{array}{l}\text { Reduced } \\
\text { Reduced }\end{array}$ & $\begin{array}{l}\text { Normal } \\
\text { Normal }\end{array}$ \\
\hline
\end{tabular}

indicate the following. First, a relationship exists between the receiving of anticonvulsant drugs, in particular phenytoin, and a low serum folic acid. There is usually a good correlation between the red cell and the serum folate levels ${ }^{1}$ suggesting a relationship between the former and the taking of anticonvulsant drugs. Secondly, in adults with epilepsy who have psychiatric disturbances the serum and red cell folate are abnormally low. Mean serum values for the affected patients range from $1.8 \mu \mathrm{g} / 1$ to $4 \cdot 14 \mu \mathrm{g} / 1$, and although no specific diagnosis is implicated it generally seems that the patients who are more severely psychiatrically disturbed, particularly the psychotic and demented, are those with the lowest mean values. Further, abnormally low levels are noted in both in-patient and out-patient studies, ${ }^{5}$ suggesting that the association is not solely due to hospitalisation. Thirdly, a relationship has been shown between low serum folic acid levels and psychiatric disturbances in patients who do not have epilepsy. The studies indicate that psychiatric patients tend to be significantly over-represented in the groups with very low serum folic acid levels, although in one study mean serum folic acid levels in psychiatric patients did not differ from normal controls. ${ }^{5}$ Again for the non-epileptic population no particular psychiatric diagnosis is implicated, although a relationship between folate deficiency and higher scores on a depression rating scale has been reported. ${ }^{7}$

The results presented here are in accordance with the results of other workers indicating low serum folate values in patients with epilepsy. Although there have been other studies on epileptic children indicating that they are susceptible to anticonvulsant-induced folic acid deficiency, ${ }^{8}$ this is the first study of the association between folate deficiency and neuropsychiatric disturbances in children. As with the studies in adults there is a relationship between a low serum folic acid and neuropsychiatric disorders, in particular a fall in IQ, neurotic disturbances and depression. The findings of a low serum folic acid in patients with a fall in IQ conforms to the findings in adult patients of low serum values in patients who have dementia. The fact that not all behaviour disturbances measured here appear to be associated with a low serum folate is interesting. As reported elsewhere conduct disorder appears more highly associated with early brain damage; and psychomotor slowing with increased seizure frequency (Trimble and Corbett-in preparation).

With regard to the red cell folate estimations few other studies have been conducted. Whole blood folate has been reported by some to be normal in epileptic patients with psychiatric abnormalities, ${ }^{9}$ although Reynolds et al, ${ }^{5}$ whose own work did show a fall in red cell folate values in adult epileptic patients with psychiatric illness, suggested that the results of Jensen and Olesen ${ }^{18}$ were in fact below the lower limit of normal. The red cell folate values reported here for the whole population are low compared to control values, and the means of the patients with neuropsychiatric disturbances are all below that which 
one would expect for other populations. In particular, patients with neurotic disturbances and depression have significantly lower values than the rest. The results for the fall in IQ group, although lower, are not significant.

As indicated in table 2, nearly all studies in this field suggest a relationship between low folate and psychiatric disturbances in both epileptic and non-epileptic patients: the exact role of this deficiency in the development of neuropsychiatric disturbance in non-anaemic patients is, however, still a matter of debate. It seems clear that for some patients the deficiency may arise from either nutritional disturbances, or as a side effect of receiving certain drugs, in particular anticonvulsants. Indeed in this study we confirmed the relationship between low serum folate values and the prescription of phenytoin. However, nutritional deficiency from poor diet does not explain all the findings ${ }^{23}$ and the main question is whether the abnormalities of folic acid metabolism discovered are in any way causal in the production of neuropsychiatric disturbances. Reynolds' view is that "severe folate deficiency gradually leads to apathy, depression, social withdrawal and ultimately dementia. ${ }^{1} \mathrm{He}$ supported this with observations that treatment with folic acid leads to increased drive, alertness and improvement of mood in epileptic patients with folic acid deficiency. ${ }^{3}$ However, several double-blind studies have been conducted of folic acid in epileptic patients with measurement of mood states, all of which have failed to show any change up to a period of six months. ${ }^{17}{ }^{24}$ These results have been criticised by Reynolds ${ }^{1}$ who claimed that most of them were conducted on deteriorated epileptic patients for an inadequate period of time. While changes in serum folic acid may be seen within a period of six months, it takes considerably longer for replacement to occur in the central nervous system.

Our studies suggest that for the group of epileptic patients we have studied folate deficiency may be observed at an early age. It is possible to relate low levels of both serum and red cell folate to patterns of neuropsychiatric illness, especially fall in IQ, depression and neurotic disorder. Epilepsy, in particular severe epilepsy which has started in childhood, tends to require treatment over many years, so that it is likely that the children studied will continue their anticonvulsant drugs, and thus have folic acid deficiency through to adulthood. It is suggested that some of them will be susceptible to develop neuropsychiatric complications as a consequence of this. Folic acid deficiency may be a link in a chain of deficiencies which ultimately result in disturbances of neurotransmitter function leading to the abnormalities described, since folic acid probably plays a role in central monoamine metabolism. ${ }^{1}$ Alterations of monoamine activity can produce dramatic changes in the mental state, ${ }^{25}$ which link may explain some of the relationship between folate deficiency and neuropsychiatric symptoms.

We thank the staff of Lingfield Hospital School, in particular Dr TC Nicol and Dr P Dupré, for their help and encouragement with this project, and the Department of Clinical Pathology, Redhill General Hospital, for their help with the assays, especially Miss G Webb. We are grateful to the school psychologist, M Weisman, for providing the psychological test data.

\section{References}

1 Reynolds EH. Neurological aspects of folate and $\mathrm{B}_{12}$ metabolism. Clinics in Haematology 1976; 5:661-94.

2 Melamed E, Reches A, Hershko C. Reversible central nervous system dysfunction in folate deficiency. J Neurol Sci 1975; 25:93-8.

3 Reynolds EH. Schizophrenia-like psychoses of epilepsy and disturbances of folate and $\mathbf{B}_{12}$ metabolism induced by anticonvulsant drugs. $B r$ J Psychiatry 1967; 113:911-9.

4 Reynolds EH, Preece J, Chanarin I. Folic acid and anticonvulsants. Lancet 1969; 1:1264-5.

5 Reynolds EH, Preece J, Johnson AL. Folate metabolism in epileptic and psychiatric patients. J Neurol Neurosurg Psychiatry 1971; 34:726-32.

6 Rutter M, Graham P, Yule W. A neuropsychiatric study in childhood. Philadelphia: William Heinemann, 1970.

7 Reynolds EH, Preece JM, Bailey J, Coppen A. Folate deficiency in depressive illnesses. $\mathrm{Br} J$ Psychiatry 1970; 117:287-92.

8 Maxwell JD, Hunter J, Stewart DA, Ardeman S, Williams R. Folate deficiency after anticonvulsant drugs: an effect of hepatic enzyme induction. $\mathrm{Br}$ Med J 1972; 1:297-9.

9 Jensen ON, Olesen OV. Folic acid concentrations in psychiatric patients. Acta Psychiatr Scand 1969; 45:289-94.

10 Callaghan N, Mitchell R, Cotter P. The relationship of serum folic acid and vitamin $B_{12}$ levels to psychosis in epilepsy. Ir J Med Sci 1969; 2: 497-505.

11 Snaith RP, Mehta S, Raby AH. Serum folate and vitamin $B_{13}$ in epileptics with and without mental illness. Br J Psychiatry 1970: 116:179-83.

12 Hurdle ADF, Picton Williams TC. Folic acid deficiency in elderly patients admitted to hospital. Br Med J 1966; 2:202-5.

13 Carney MWP. Serum folate values in 423 psychi- 
atric patients. Br Med $J$ 1967; 4:512-6.

14 Hunter R, Jones M, Jones TG, Matthews DM. Serum $B_{12}$ and folate concentrations in mental patients. Br J Psychiatry 1967; 113:1291-5.

15 Ibbotson RN, Dilena BA, Horwood JM. Studies on deficiency and absorption of folates in patients on anticonvulsant drugs. Aust Ann Med 1967; 16:144-60.

16 Shulman R. A survey of vitamin $B_{12}$ deficiency in an elderly psychiatric population. $\mathrm{Br} J$ Psychiatry 1967; 113:241-51.

17 Hällström $T$. Serum $B_{12}$ and folate concentrations in mental patients. Acta Psychiatr Scand 1969; 45:19-36.

18 Jensen ON, Olesen OV. Subnormal serum folate due to anticonvulsant therapy. Arch Neurol 1970; 22:181-2.

19 Kariks J, Perry SW. Folic acid deficiency in psychiatric patients. Med J A ust 1970; 1:1192-5.
20 Källström B, Nylof R. Vitamin $B_{12}$ and folic acid in psychiatric patients. Acta Psychiatr Scand 1969; 45:137-52.

21 Sneath P, Chanarin I, Hodgkinson HM, McPherson CK, Reynolds EH. Folate status in a geriatric population and its relation to dementia. Age Ageing 1973; 2:177-82.

22 Carney MWP, Sheffield BF. Serum folic acid and $\mathrm{B}_{12}$ in 272 psychiatric in-patients. Psychol Med 1978; 8:139-44.

23 Thornton WE, Thornton BP. Folic acid, mental function and dietary habits. $J$ Clin Psychiatry 1978; 39:315-22.

24 Grant RHE, Stores OPR. Folic acid and folate deficient patients with epilepsy. Br Med J 1970; 4:644-8.

25 Trimble MR, Chadwick D, Reynolds EH, Marsden CD. L-5HTP and mood. Lancet 1975; 1:583. 